\title{
Hematological Profile of Patients Having Malaria-positive Peripheral Blood Smears: A Cross-sectional Study at a Diagnostic Research Center in Khyber Pakhtunkhwa, Pakistan
}

\author{
Inam Ullah ${ }^{1}$, Muhammad U. Ali ${ }^{2}$, Saeed Ali $^{3}$, Ahmad Rafiq ${ }^{1}$, Zeeshan Sattar ${ }^{4}$, Sana \\ Hussain ${ }^{4}$ \\ 1. Pathology, Khyber Medical College, Peshawar, PAK 2. General Surgery, Royal Lancaster Infirmary, \\ Lancaster, GBR 3. Internal Medicine, Florida Hospital, Orlando, USA 4. Internal Medicine, Khyber \\ Teaching Hospital, Peshawar, PAK
}

$\square$ Corresponding author: Zeeshan Sattar, zeeshi16@gmail.com Disclosures can be found in Additional Information at the end of the article

\section{Abstract}

Malaria is a life-threatening infectious disease that, in severe cases, is associated with calamitous complications and far-reaching consequences within a community. It is usually manifested by abnormalities in various hematological indices with anemia and thrombocytopenia being the most frequent ones. The present study sheds light on the laboratory profile of patients suffering from malaria and provides a comprehensive analysis and correlation with the available literature worldwide. The study was carried out as a crosssectional study at OK Diagnostic Lab and Research Center in Peshawar from October 2010 to October 2013. All malaria parasite (MP)-positive cases reported at OK Lab during the study period were employed in the study, making a total of 136 MP positive cases. Complete blood pictures with platelet counts were obtained in all patients and various hematological indices were analyzed according to the World Health Organization (WHO) criteria. Thrombocytopenia was defined as a platelet count of $<150 \times 10^{3} / \mathrm{cmm}$ and anemia as an hemoglobin $(\mathrm{Hb})<13 \mathrm{~g} / \mathrm{dL}$ in males and $<12 \mathrm{~g} / \mathrm{dL}$ in females. Among the $136 \mathrm{MP}$ positive patients, 74 (55.4\%) had associated thrombocytopenia while 105 (77.2\%) patients showed anemia on a peripheral blood smear. This was followed by leukopenia in $8.8 \%$ of cases. Among patients with Plasmodium falciparum ( $P$. falciparum) infection, anemia was present in $80 \%$ of cases as compared to $74 \%$ cases with $P$. vivax infection ( $\mathrm{p}=0.5$ ). Thrombocytopenia was associated with $P$. vivax infection in $71.4 \%$ of cases in contrast to P. falciparum infection, where $26 \%$ of cases had associated thrombocytopenia $(\mathrm{p}=0.01)$. On the contrary, leukopenia was more prevalent in $P$. falciparum patients (18\%), followed by P. vivax (2.6\%), and mixed parasitemia $(11.1 \%)(\mathrm{p}<0.001)$. In

Received 08/20/2018 Review began 08/20/2018 Review ended 09/11/2018 Published 09/27/2018

\section{(c) Copyright 2018}

Ullah et al. This is an open access article distributed under the terms of the Creative Commons Attribution License CC-BY 3.0., which permits unrestricted use, distribution, and reproduction in any medium, provided the original author and source are credited. addition, the study showed statistically significant variations in hematocrit (Hct), mean corpuscular volume (MCV), mean corpuscular hemoglobin concentration (MCHC), and platelet counts across different malarial species $(\mathrm{p}<0.05)$. Likewise, variations within mean Hct levels among males and females were statistically significant, with females showing lower mean Hct levels than males $(\mathrm{p}<0.05)$.

Categories: Internal Medicine, Infectious Disease, Epidemiology/Public Health Keywords: malaria, thrombocytopenia, p. falciparum, p. vivax, leukopenia, anemia, khyber pakhtunkhwa

\section{How to cite this article}

Ullah I, Ali M U, Ali S, et al. (September 27, 2018) Hematological Profile of Patients Having Malaria-positive 


\section{Introduction}

Malaria is considered to be a life-threatening infectious disease that, in severe cases, is associated with calamitous complications and can inflict drastic and far-reaching consequences within a community. The existence of this disease can be traced back to 2700 years BC in China and historians have even reported Alexander to be a victim of it during the battle of Mesopotamia in the fourth century BC [1]. The disease is caused by infection with a parasitic unicellular organism of genus Plasmodium, which gets injected into the human bloodstream through the bite of a female Anopheles mosquito [2]. Traditionally four species of Plasmodium, including P. falciparum, P. vivax, $P$. ovale, and P. malariae, have been known to cause infections in humans. However, another species, $P$. knowlesi which causes malaria in macaque monkeys [3], has been reported to cause malaria in humans [4]. Since 2004, increasing data has been published with regards to an increase in its incidence in various Southeast Asian countries [5].

According to the World Health Organization (WHO) estimates, $40 \%$ of the world's population is at risk of developing malaria [1]. Studies have reported a global incidence of $300-500$ million cases per year with an associated two million deaths per annum [1]. Likewise, in Pakistan, the disease plays havoc with lives of millions per year and local literature reveals higher mortality rates among infants, children, and pregnant women. The National Malaria Control Program of Pakistan has reported a six-fold increase in the incidence of $P$. falciparum malaria that now comprises $42 \%$ of all malaria cases reported in the country [6]. Therefore, in addition to being a major public health issue, the disease significantly adds to the country's economic burden.

In addition to the typical features, including high-grade fever, shivering, vomiting, and jaundice, malaria is frequently associated with hemolytic anemia, hemoglobinuria, and varying degrees of thrombocytopenia [1,7], with cerebral malaria and renal failure being the most dreaded complications. Although various studies have reported thrombocytopenia in association with malaria as a common finding $[1,8]$, its correlation with the type of malaria and various hematological parameters has not been evaluated extensively in large studies. In view of the paucity of data from Pakistan, we have attempted to throw some light on the laboratory profile of patients suffering from malaria by analyzing and correlating various hematological indices and comparing them with the available literature worldwide.

\section{Materials And Methods}

This study was conducted as a cross-sectional study analyzing all the malaria parasite (MP)positive peripheral blood smears of cases reported at the OK Quality Diagnostic Laboratory and Research Center in Peshawar from October 2010 to October 2013. The Ethics Committee of Khyber Medical College/Khyber Teaching Hospital, Peshawar approved this study. OK Quality Laboratory is a welfare diagnostic center that receives patients from across the city, including the main tertiary referral centers. Blood samples of all the patients referred for peripheral blood smear were drawn through venipuncture by professional staff into a $3 \mathrm{~mL}$ tube with ethylenediaminetetraacetic acid (EDTA) and were also analyzed for malarial parasites with conventional microscopy. Hemoglobin (Hb), hematocrit (Hct), mean corpuscular volume (MCV), mean corpuscular hemoglobin (MCH), mean corpuscular hemoglobin concentration (MCHC), red blood cell (RBC) count, total leukocyte count (TLC), and platelet count were determined by using a hematology analyzer, HumaReader Plus (HUMAN Diagnostic Worldwide, Wiesbaden, Germany)

All individuals who possessed MP-positive peripheral smears were included in the study and each patient's records were analyzed for age, gender, and species of malarial parasite involved. Various hematological indices were analyzed using the WHO criteria [9]. For hemoglobin, the cut-off criterion indicating anemia was $12 \mathrm{~g} / \mathrm{dL}$ for females and $13 \mathrm{~g} / \mathrm{dL}$ for males. Hematocrit 


\section{Cureus}

was considered to be abnormal at values $<36 \%$ for females and $<41 \%$ for males. Likewise, $\mathrm{RBC}$ count for males was considered normal in the range of $4.2-5.8 \times 106 /$ cubic millimeter $(\mathrm{cmm})$ and between $3.6-5.6 \times 106 / \mathrm{cmm}$ was considered within normal limits for females. The cut-off values for RBC indices indicating anemia were as follows: MCV $<80$ femtoliters (fL), MCH $<27$ picograms (pg), and MCHC < 32 grams per deciliter (g/dL). Similarly, platelets $<150 \times 103 / \mathrm{cmm}$ and TLC values $<4 \times 103 / \mathrm{cmm}$ were considered abnormal (Table 1 ).

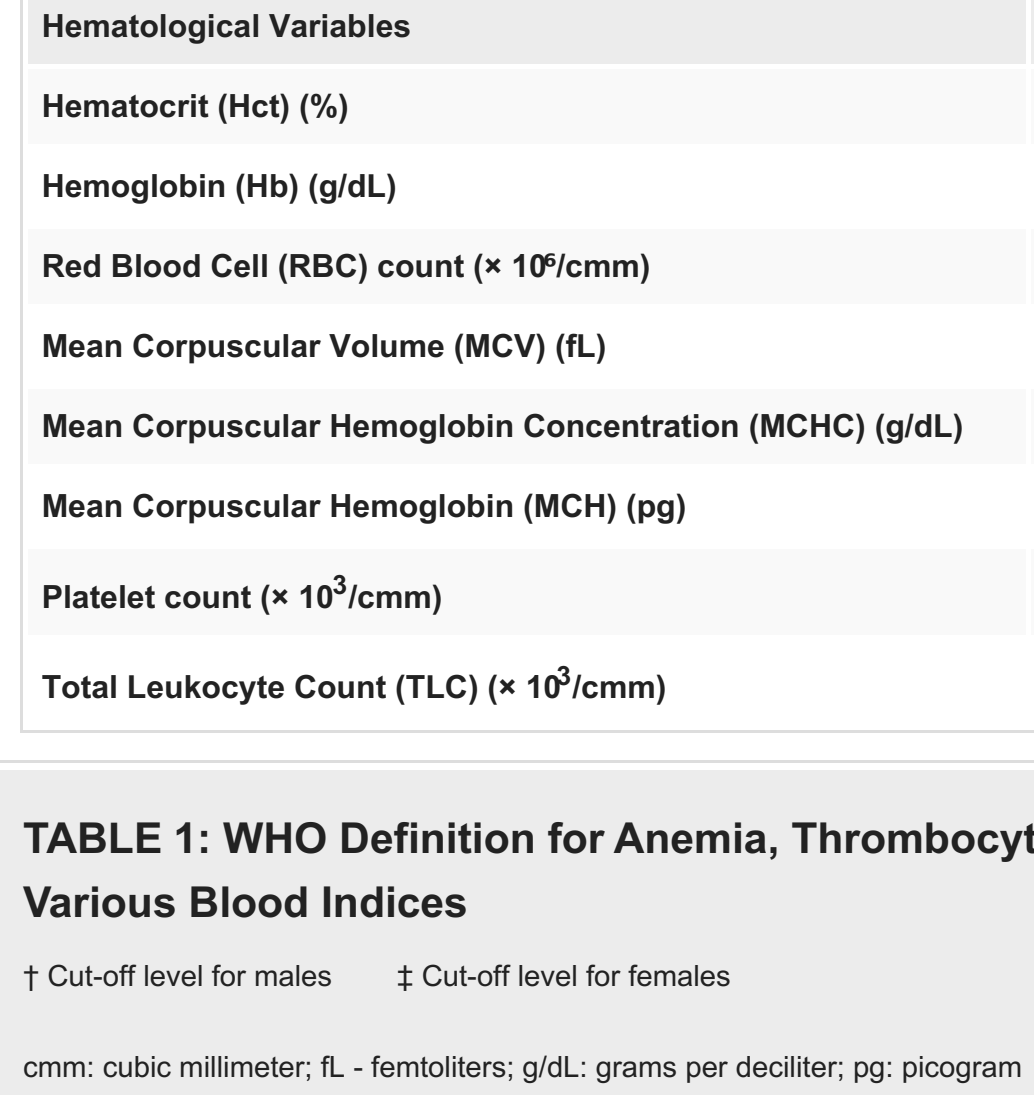
Various Blood Indices

† Cut-off level for males $\quad \ddagger$ Cut-off level for females

cmm: cubic millimeter; fL - femtoliters; g/dL: grams per deciliter; pg: picogram

World Health Organization (WHO) Criteria [9]

$<41 \% \dagger \&<36 \% \ddagger$

$<13 \mathrm{~g} / \mathrm{dL} † \&<12 \mathrm{~g} / \mathrm{dL}+$

$<4.2 \times 10^{6} / \mathrm{cmm} \dagger \&<3.6 \times 10^{6} / \mathrm{cmm} \ddagger$

$<80 \mathrm{fL}$

$<32 \mathrm{~g} / \mathrm{dL}$

$<27 \mathrm{pg}$

$<150 \times 10^{3} / \mathrm{cmm}$

$<4.0 \times 10^{3} / \mathrm{cmm}$

\section{TABLE 1: WHO Definition for Anemia, Thrombocytopenia, and Leukopenia Based on}

All the data were analyzed using the Statistical Package for Social Sciences (SPSS), version 17.0 (IBM SPSS Statistics, Armonk, NY), and the means of different scale variables were analyzed and compared using Student's t-test and the analysis of variance (ANOVA) test (depending upon the variable groups). Similarly, all the non-parametric variables were analyzed using the Chi-square test of independence $(\varkappa 2)$. Results were considered statistically significant when the $\mathrm{p}$-value was $<0.05$ at $95 \%$ level of significance. An extensive literature search was done using the PubMed database and Google Scholar, while references were cited using the Endnote X1 library.

\section{Results}

A total of $136 \mathrm{MP}$-positive patients were included in the study of which 72 (52.9\%) were males and $64(47.1 \%)$ were females with a male to female ratio of 1.12:1. The mean age of patients was $25.8 \pm 18.44$ years (range: 0.6 - 75 years). Out of total 136 cases, 77 (56.6\%) were positive for $P$. vivax malaria, 50 (36.8\%) for P. falciparum malaria, and nine (6.6\%) patients had mixed parasitemia, including both $P$. vivax and $P$. falciparum malarial parasites. However, male to female ratio did not vary significantly across different malarial species, $\mathrm{p}=0.84, \varkappa 2=0.958$.

Mean $\mathrm{Hb}(10.35 \pm 3.4 \mathrm{~g} / \mathrm{dL})$, Hct $(30.7 \pm 9.3 \%)$, RBC count $\left(3.9 \pm 1.24 \times 106 / \mathrm{mm}^{3}\right)$, and MCV 


\section{Cureus}

values $(78.2 \pm 9.2 \mathrm{fL})$ were below cut-off limits with regards to WHO criteria [9], thus indicating microcytic hypochromic anemia, whereas means of other variables, like MCH (27.25 $\pm 7.1 \mathrm{pg})$, MCHC $(33.29 \pm 3.4 \mathrm{~g} / \mathrm{dL})$, TLC $\left(9.3 \pm 7.8 \times 103 / \mathrm{mm}^{3}\right)$, and platelet count $\left(167 \pm 108 \times 103 / \mathrm{mm}^{3}\right)$, were within normal range. Overall, $\mathrm{Hb}$ was low in $77.2 \%$ of patients, Hct in $81.6 \%$ patients, and MCV was found low in $57.3 \%$ cases, again showing that majority of our patients were anemic having a microcytic hypochromic picture. Since cut-off limits for Hb, Hct, and RBC count, based on WHO criteria [9], were different for males and females, Figure 1 further elaborates their gender-wise relative frequencies.

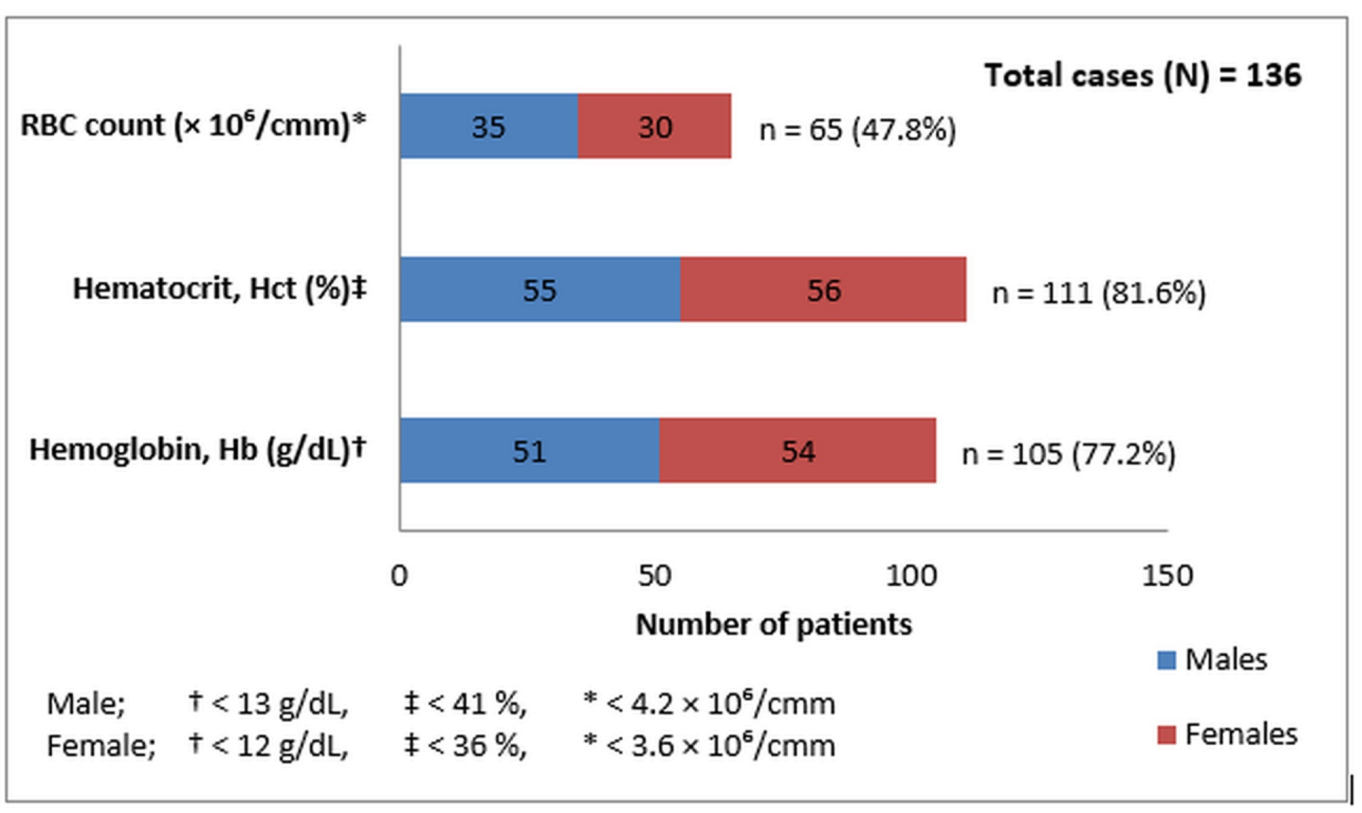

FIGURE 1: Gender-wise Frequency of Anemic Patients Based on WHO Cut-off Levels for Different Blood Indices

WHO: World Health Organization; RBC: red blood cell; cmm: cubic millimeter; g/dL: grams per deciliter; n: number

Figure 2 shows the prevalence of various other microscopic findings seen on peripheral blood smears of MP-positive patients. 


\section{Cureus}

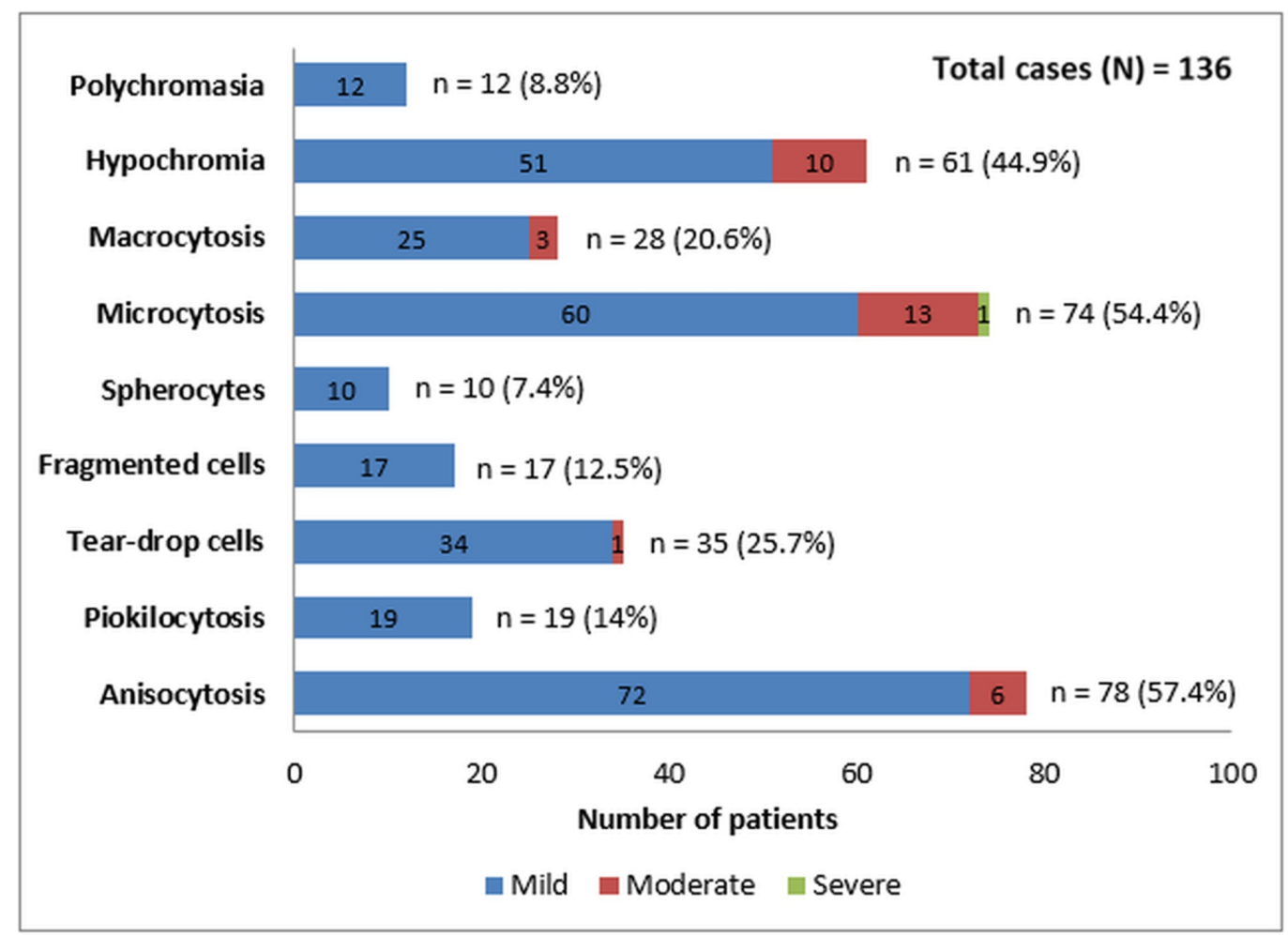

FIGURE 2: Frequencies of Various Microscopic Findings in Peripheral Blood Smear of MP-positive Patients

MP: malaria parasite

Overall, thrombocytopenia was present in 74 (54.4\%) patients and leukopenia was found in 12 (8.9\%) patients, while pancytopenia was only present in two (1.5\%) patients. In addition, their relative frequencies did not vary significantly with gender, $\mathrm{p}>0.05$ (Table 2). 


\section{Cureus}

\begin{tabular}{|c|c|c|c|c|c|c|}
\hline Variables & $\begin{array}{l}\text { WHO cut-off } \\
\text { levels [10] }\end{array}$ & $\begin{array}{l}\text { Males } \dagger \\
n=72\end{array}$ & $\begin{array}{l}\text { Females } \ddagger \\
n=64\end{array}$ & $\begin{array}{l}\text { Frequency } \\
(\%)\end{array}$ & $\begin{array}{l}\text { Chi- } \\
\text { square } \\
\left(x^{2}\right)\end{array}$ & $\begin{array}{l}P \text { - } \\
\text { value }\end{array}$ \\
\hline \multirow{2}{*}{ Hemoglobin $(\mathrm{Hb})(\mathrm{g} / \mathrm{dL})$} & $<13 \dagger \&<12 \ddagger$ & 51 & 54 & 105 (77.2) & \multirow{2}{*}{3.53} & \multirow{2}{*}{0.06} \\
\hline & $\geq 13 \dagger \& \geq 12 \ddagger$ & 21 & 10 & $31(22.8)$ & & \\
\hline \multirow{2}{*}{ Hematocrit (Hct) (\%) } & $<41 \dagger \&<36 \ddagger$ & 55 & 56 & 111 (81.6) & \multirow{2}{*}{2.79} & \multirow{2}{*}{0.09} \\
\hline & $\geq 41 \dagger \& \geq 36 \ddagger$ & 17 & 8 & $25(18.4)$ & & \\
\hline \multirow{2}{*}{ Red Blood Cell (RBC) count $\left(\times 10^{6} / \mathrm{cmm}\right)$} & $<4.2 \dagger \&<3.6 \ddagger$ & 35 & 30 & $65(47.8)$ & \multirow{2}{*}{0.04} & \multirow{2}{*}{0.84} \\
\hline & $\geq 4.2 \dagger \& \geq 3.6 \ddagger$ & 37 & 34 & $71(52.2)$ & & \\
\hline \multirow{2}{*}{ Mean Corpuscular Volume (MCV) (fL) } & $<80$ & 41 & 37 & $78(57.3)$ & \multirow{2}{*}{0.01} & \multirow{2}{*}{0.92} \\
\hline & $\geq 80$ & 31 & 27 & $58(42.7)$ & & \\
\hline \multirow{2}{*}{$\begin{array}{l}\text { Mean Corpuscular Hemoglobin (MCH) } \\
\text { (pg) }\end{array}$} & $<27$ & 35 & 37 & $72(52.9)$ & \multirow{2}{*}{1.15} & \multirow{2}{*}{0.28} \\
\hline & $\geq 27$ & 37 & 27 & $64(47.1)$ & & \\
\hline \multirow{2}{*}{$\begin{array}{l}\text { Mean Corpuscular Hemoglobin } \\
\text { Concentration (MCHC) (g/dL) }\end{array}$} & $<32$ & 29 & 24 & 53 (39) & \multirow{2}{*}{0.1} & \multirow{2}{*}{0.74} \\
\hline & $\geq 32$ & 43 & 40 & $83(61)$ & & \\
\hline \multirow{2}{*}{$\begin{array}{l}\text { Total Leukocyte Count (TLC) }(\times \\
\left.10^{3} / \mathrm{cmm}\right)\end{array}$} & $<4$ & 5 & 7 & $12(8.8)$ & \multirow{2}{*}{0.67} & \multirow{2}{*}{0.4} \\
\hline & $\geq 4$ & 67 & 57 & $124(91.2)$ & & \\
\hline \multirow{2}{*}{ Platelet count $\left(\times 10^{3} / \mathrm{cmm}\right)$} & $<150$ & 36 & 38 & 74 (54.4) & \multirow{2}{*}{1.2} & \multirow{2}{*}{0.27} \\
\hline & $\geq 150$ & 36 & 26 & $62(45.6)$ & & \\
\hline
\end{tabular}

\section{TABLE 2: Gender-wise Relative Frequencies of Different Hematological Variables in}

\section{MP-positive Patients}

† Cut-off level for males $\quad \ddagger$ Cut-off level for females $\quad *$ Significant at $95 \%$ level of significance

MP: malaria parasite; WHO: World Health Organization; P-value: calculated probability; cmm: cubic millimeter; fL: femtoliters; g/dL: grams per deciliter; pg: picogram 


\section{Cureus}

\begin{tabular}{|c|c|c|c|c|c|c|}
\hline Variables & $\begin{array}{l}\text { WHO cut- } \\
\text { off levels }\end{array}$ & $\begin{array}{l}P . \\
\text { falciparum } \mathrm{n} \\
=50(\%)\end{array}$ & $\begin{array}{l}\text { P. vivax n } \\
=77(\%)\end{array}$ & $\begin{array}{l}P . \text { falciparum \& } P \text {. } \\
\text { vivax } \mathrm{n}=9(\%)\end{array}$ & $\begin{array}{l}\text { Frequency } \\
(\%)\end{array}$ & $\begin{array}{l}P- \\
\text { value }\end{array}$ \\
\hline \multirow{2}{*}{ Hemoglobin (Hb) (g/dL) } & $\begin{array}{l}<12 \nmid \&< \\
13 \ddagger\end{array}$ & $40(80)$ & $57(74)$ & $8(88.9)$ & 105 (77.2) & \multirow{2}{*}{0.5} \\
\hline & $\begin{array}{l}\geq 12 \dagger \& \geq \\
13 \ddagger\end{array}$ & $10(20)$ & $20(26)$ & $1(11.1)$ & $31(22.8)$ & \\
\hline \multirow{2}{*}{ Hematocrit (Hct) (\%) } & $\begin{array}{l}<41 \dagger \&< \\
36 \ddagger\end{array}$ & $42(84)$ & $62(80.5)$ & $7(77.8)$ & $111(81.6)$ & \multirow{2}{*}{0.84} \\
\hline & $\begin{array}{l}\geq 41 † \& \geq \\
36 \ddagger\end{array}$ & $8(16)$ & $15(19.5)$ & $2(22.2)$ & $25(18.4)$ & \\
\hline \multirow{2}{*}{$\begin{array}{l}\text { Red Blood Cell (RBC) count (x } \\
\left.10^{6} / \mathrm{cmm}\right)\end{array}$} & $\begin{array}{l}<4.2 \dagger \&< \\
3.6 \neq\end{array}$ & $27(54)$ & $33(42.9)$ & $5(55.6)$ & $65(47.8)$ & \multirow{2}{*}{0.41} \\
\hline & $\begin{array}{l}\geq 4.2 \dagger \& \geq \\
3.6 \ddagger\end{array}$ & $23(46)$ & $44(57.1)$ & $4(44.4)$ & $71(52.2)$ & \\
\hline \multirow{2}{*}{$\begin{array}{l}\text { Mean Corpuscular Volume } \\
\text { (MCV) (fL) }\end{array}$} & $<80$ & $34(68)$ & $39(50.6)$ & $5(55.6)$ & $78(57.4)$ & \multirow{2}{*}{0.15} \\
\hline & $\geq 80$ & $16(32)$ & $38(49.4)$ & $4(44.4)$ & $58(42.6)$ & \\
\hline \multirow{2}{*}{$\begin{array}{l}\text { Mean Corpuscular Hemoglobin } \\
(\mathrm{MCH})(\mathrm{pg})\end{array}$} & $<27$ & $25(50)$ & $42(54.5)$ & $5(55.6)$ & $72(52.9)$ & \multirow{2}{*}{0.86} \\
\hline & $\geq 27$ & $25(50)$ & $35(45.5)$ & $4(44.4)$ & $64(47.1)$ & \\
\hline \multirow{2}{*}{$\begin{array}{l}\text { Mean Corpuscular Hemoglobin } \\
\text { Concentration (MCHC) (g/dL) }\end{array}$} & $<32$ & $16(32)$ & $34(44.2)$ & $3(33.3)$ & $53(39)$ & \multirow{2}{*}{0.36} \\
\hline & $\geq 32$ & 34 (68) & $43(55.8)$ & $6(66.7)$ & $83(61)$ & \\
\hline \multirow{2}{*}{$\begin{array}{l}\text { Total Leukocyte Count (TLC) }(\times \\
\left.10^{3} / \mathrm{cmm}\right)\end{array}$} & $<4$ & $9(18)$ & $2(2.6)$ & $1(11.1)$ & $12(8.8)$ & \multirow{2}{*}{$0.01^{*}$} \\
\hline & $\geq 4$ & $41(82)$ & $75(97.4)$ & $8(88.9)$ & $124(91.2)$ & \\
\hline \multirow{2}{*}{ Platelet count $\left(\times 10^{3} / \mathrm{cmm}\right)$} & $<150$ & $13(26)$ & $55(71.4)$ & $6(66.7)$ & $74(54.4)$ & \multirow{2}{*}{$\begin{array}{l}< \\
0.001^{*}\end{array}$} \\
\hline & $\geq 150$ & 37 (74) & $22(28.6)$ & 3 (33.3) & $62(45.6)$ & \\
\hline
\end{tabular}

TABLE 3: Relative Frequencies of Various Hematological Indices Among Different Malarial Species

† Cut-off level for males $\quad \ddagger$ Cut-off level for females * Significant at $95 \%$ level of significance

WHO: World Health Organization; P: Plasmodium; P-value: calculated probability; N: number; cmm: cubic millimeter; fL:

femtoliters; g/dL: grams per deciliter; pg: picogram

Using hematological indices as scale variables mean hemoglobin concentration was $9.1 \mathrm{~g} / \mathrm{dL}$ in subjects with $P$. falciparum malaria, $10.7 \mathrm{~g} / \mathrm{dL}$ in patients with $P$. vivax, and $9.86 \mathrm{~g} / \mathrm{dL}$ in cases having a mixed infection with $P$. Falciparum and $P$. vivax parasites. However, the ANOVA test 
did not reveal any statistically significant variation in mean hemoglobin concentration across different malarial species, $\mathrm{p}=0.39$. The lowest hemoglobin concentration was $2.7 \mathrm{~g} / \mathrm{dL}$ in $P$. falciparum infection and $5.4 \mathrm{~g} / \mathrm{dL}$ in $P$. vivax parasitemia. The mean platelet count in $P$. vivax malaria was $135.8 \pm 89.4 \times 103 / \mathrm{cmm}$ as compared to $P$. falciparum and mixed species infection, where the mean platelet count was $222 \pm 118.7 \times 103 / \mathrm{cmm}$ and $141.8 \pm 70.5 \times 103 / \mathrm{cmm}$, respectively. The ANOVA test showed the difference to be statistically significant with $\mathrm{F}=11.5$, $\mathrm{p}<0.0001$. Likewise, the mean values of the Hct, MCV, and MCHC showed a statistically significant variation when compared across different malarial species, $\mathrm{p}<0.05$ (Table 4).

VARIABLES
Hematocrit (Hct) (\%)
Hemoglobin (Hb) (g/dL)
Mean Corpuscular Volume (MCV)

(fL)

\author{
Red Blood Cell (RBC) count ( $\times$ \\ $10 \% \mathrm{cmm}$ )
}
Mean Corpuscular Hemoglobin Cenctration (MCHC) (g/dL)

Mean Corpuscular Hemoglobin (MCH) (pg)

Platelet count $\left(\times 10^{3} / \mathrm{cmm}\right)$

Total Leukocyte Count (TLC) ( $x$ $10^{3} / \mathrm{cmm}$ )

P. falciparum
Mean \pm SD

$P$. vivax
Mean \pm SD

$27.8 \pm 10.74$

$32.7 \pm 7.17$

$9.9 \pm 4.48$

$76.52 \pm 9.9$

$3.65 \pm 1.51$

$34.32 \pm 3.6$

$27.93 \pm 8.6$

$26.34 \pm 3.26$

$222 \pm 118.7$

$135.8 \pm 89.4$

$10.4 \pm 11.4$

$8.7 \pm 4.5$

$8.12 \pm 4.3$

0.86
$31.25 \pm 16.37$

$141.8 \pm 70.5$

P. falciparum \& $P$. vivax Mean \pm SD

$30.6 \pm 13.0$

$9.86 \pm 3.81$

$73.7 \pm 19.0$

$3.82 \pm 1.76$

1.87

0.15

$3.7 \quad 0.02^{*}$

$2.3 \quad 0.1$

11.5

$<$

$0.0001^{*}$

\section{TABLE 4: Mean Values of Various Hematological Indices Across Different Malarial Species}

* Significant at $95 \%$ level of significance

P: Plasmodium; P-value: calculated probability; SD: standard deviation; cmm: cubic millimeter; fL: femtoliters; g/dL: grams per deciliter; pg: picogram

Analyzing various hematological indices as categorical variables and using cut-off levels in accordance with WHO criteria of anemia [9], the Chi-square test $(\varkappa 2)$ revealed no gender-wise statistically significant variation in their relative frequencies, $p>0.05$ (Table 5). In contrast, when analyzing these indices as scale variables, the mean Hct was found to be $32.7 \pm 9.2 \%$ in males and $28.5 \pm 8.9 \%$ in females. Using the Student's T-test, such variation was found to be statistically significant, $\mathrm{p}=0.007$. However, other variables did not show any significant gender-wise variation in their relative frequencies when analyzed as a scale variable using the Student's T-test (Table 5). 


\section{Cureus}

\begin{tabular}{|c|c|c|c|c|}
\hline VARIABLES & $\begin{array}{l}\text { Males Mean } \pm \\
\text { SD }\end{array}$ & $\begin{array}{l}\text { Females Mean } \pm \\
\text { SD }\end{array}$ & $\begin{array}{l}\text { Student's T- } \\
\text { test }\end{array}$ & $\begin{array}{l}P- \\
\text { value }\end{array}$ \\
\hline Hemoglobin (Hb) (g/dL) & $10.8 \pm 3.13$ & $9.7 \pm 3.6$ & 1.91 & 0.058 \\
\hline Hematocrit (Hct) (\%) & $32.7 \pm 9.2$ & $28.5 \pm 8.9$ & 2.7 & $0.008^{*}$ \\
\hline Red Blood Cell (RBC) count $\left(\times 10^{6} / \mathrm{cmm}\right)$ & $4.09 \pm 1.08$ & $3.70 \pm 1.37$ & 1.85 & 0.06 \\
\hline Mean Corpuscular Volume (MCV) (fL) & $77.3 \pm 11.16$ & $79.3 \pm 6.19$ & 1.27 & 0.20 \\
\hline Mean Corpuscular Hemoglobin (MCH) (pg) & $27.84 \pm 9.12$ & $26.5 \pm 3.65$ & 1.09 & 0.27 \\
\hline $\begin{array}{l}\text { Mean Corpuscular Hemoglobin Concentration } \\
(\mathrm{MCHC})(\mathrm{g} / \mathrm{dL})\end{array}$ & $33.16 \pm 3.66$ & $33.43 \pm 3.19$ & 0.46 & 0.64 \\
\hline Total Leukocyte (TLC) $\left(\times 10^{3} / \mathrm{cmm}\right)$ & $9.2 \pm 9.33$ & $9.47 \pm 5.6$ & 0.20 & 0.83 \\
\hline Platelet count $\left(\times 10^{3} / \mathrm{cmm}\right)$ & $180.1 \pm 107.7$ & $154.2 \pm 107.1$ & 1.40 & 0.16 \\
\hline
\end{tabular}

\section{TABLE 5: Means of Various Hematological Variables in MP-positive Males and Females}

* Significant at $95 \%$ level of significance

MP: malaria parasite; SD: standard deviation; P-value: calculated probability; cmm: cubic millimeter; fL: femtoliters; g/dL: grams per deciliter; pg: picogram

\section{Discussion}

Malaria typically affects blood indices in various ways with anemia and thrombocytopenia being the frequent associated hematological outcomes. Studies have reported thrombocytopenia as a sensitive marker for a malaria diagnosis in the presence of acute febrile illness, having a sensitivity of $60 \%$, a specificity of $88 \%$ [10], and a positive and negative predictive value of $86 \%$ and $100 \%$, respectively [11]. Although the exact mechanism of thrombocytopenia in malaria is still a topic of extensive worldwide research, studies have considered immunoglobulin G (IgG)-mediated platelet destruction [12], sequestration in the spleen, oxidative stress, and abnormalities in platelets' structure caused by the invasion of the parasite as possible explanations [13-14]. Researchers have also suggested thrombocytopenia as a result of consumption by disseminated intravascular coagulation (DIC) and peripheral platelet destruction induced by P. falciparum, although the latter mechanism has not been systematically evaluated in P. vivax malaria [8]. Similarly, studies have considered the peripheral destruction of RBCs, ineffective hematopoiesis, and sequestration in the spleen as possible causes of malaria-induced anemia [8]. Likewise, the role of TNF and IL-10 have been studied in the development of $P$. falciparum-induced anemia; however, such a role has not been observed in the development of malaria-induced thrombocytopenia [15].

Mild to severe thrombocytopenia should alert the possibility of a malarial infection, with thrombocytopenia being a frequent complication of $P$. vivax infection. Kochar et al. has shown the association of thrombocytopenia with $P$. vivax monoinfection as more significant when compared to thrombocytopenia in $P$. falciparum monoinfection (odds ratio $(\mathrm{OR})=2.335$ (95\% 
$\mathrm{CI} ; 1.72$ - 3.16), $\mathrm{p}<0.0001$ ) [13]. In the present study overall, $54.4 \%$ of our patients suffering from malaria showed thrombocytopenia. Out of the total 77 cases having a $P$. vivax infection, 71.4\% patients had $P$. vivax-associated thrombocytopenia (Table 3). These figures were in good agreement with studies done by other investigators showing P. vivax-associated thrombocytopenia in 63\% by Khan et al. [16], 82\% by Srivastava et al. [17], and 93.3\% by George and Alexander [18]. On the contrary, studies, such as Rodriguez-Monrale et al. [19] and Gonzalez et al. [20], have shown P. vivax-associated thrombocytopenia in $58.9 \%$ and $55.9 \%$ cases, respectively.

According to our study, only $26 \%$ of cases with $P$. falciparum infection had associated thrombocytopenia. Although this was in good agreement with studies like Casals-Pascual et al. [21] and Tan et al. [22] showing P. falciparum-related thrombocytopenia in $34.4 \%$ and $34 \%$ cases, respectively, others have reported much higher frequencies. This includes $51.8 \%$ by Noronha [23] and $85 \%$ by Prasad et al. [24].

In our study, the mean $\mathrm{Hb}$ in females $(9.7 \pm 3.6 \mathrm{~g} / \mathrm{dL})$ was lower than that in males $(10.8 \pm 3.13$ $\mathrm{g} / \mathrm{dL}$ ) with $\mathrm{p}=0.058$ (Table 5 ). These results were in good agreement with studies from Columbia and Uganda [25-26], showing a mean $\mathrm{Hb}$ in females lower than those of males in malaria patients. According to WHO criteria of anemia [9], 105 (77.2\%) of our patients were anemic with regards to Hb values (Figure 1). Similarly, a study from Uganda [26] had shown $76.8 \%$ prevalence of malaria parasitemia among severely anemic hospitalized patients in malaria-endemic regions. In our study, out of 105 anemic patients, 57/105 (54.3\%) had a $P$. vivax infection, $40 / 105$ (38.1\%) had $P$. falciparum while $8 / 105$ (7.6\%) had mixed parasitemia. However, out of nine patients with mixed parasitemia, eight (88.9\%) had anemia, while 40/50 (80\%) of $P$. falciparum and 57/77 (74\%) of $P$. vivax patients had anemia according to WHO criteria (Table 3). Again, these results were comparable to a study from Gabon [25], where the prevalence of anemia was reported between 87.6 - 90.7\% among patients having $P$. falciparum parasitemia.

In addition to having abnormalities in RBC and platelet counts, studies have reported low to normal total leukocyte counts in malaria [27-28], although none of these abnormalities are specific to malaria [29]. Likewise, Sharma et al. [29] have reported high sensitivity and positive predictive value (PPV) for a malaria diagnosis in patients with abnormal scattergram. However, in our study, only 12/136 (8.9\%) patients showed leukopenia, which was contrary to results shown by Shaikh et al. [1] who reported leukopenia in $35.4 \%$ of malaria patients. In our study, leukopenia was more common in patients suffering from $P$. falciparum infection (18\%) than from P. vivax (2.5\%) and mixed infections (11\%). This was again in contrast to studies, like McKenzie et al. [28], that showed white blood cell (WBC) counts in $P$. falciparum-infected patients were lower than those having an infection with $P$. vivax, which in turn, were lower than those in uninfected patients.

\section{Conclusions}

Malaria is frequently associated with anemia (77.2\%), thrombocytopenia (54.4\%), and leukopenia (8.8\%) of cases. In patients with anemia, $54.3 \%$ had $P$. vivax parasitemia, whereas $38.1 \%$ had $P$. falciparum infection. Thrombocytopenia was associated with $P$. vivax infection in $71.4 \%$ cases, whereas $26 \%$ had $P$. falciparum infection. On contrary, leukopenia was more prevalent in $P$. falciparum patients (18\%), followed by $P$. vivax (2.6\%) and mixed parasitemia (11.1\%).

\section{Additional Information \\ Disclosures}


Human subjects: Consent was obtained by all participants in this study. Ethics Committee of Khyber Medical College/Khyber Teaching Hospital, Peshawar issued approval N/A. Animal subjects: All authors have confirmed that this study did not involve animal subjects or tissue. Conflicts of interest: In compliance with the ICMJE uniform disclosure form, all authors declare the following: Payment/services info: All authors have declared that no financial support was received from any organization for the submitted work. Financial relationships: All authors have declared that they have no financial relationships at present or within the previous three years with any organizations that might have an interest in the submitted work. Other relationships: All authors have declared that there are no other relationships or activities that could appear to have influenced the submitted work.

\section{References}

1. Shaikh QH, Ahmad SM, Abbasi A, et al.: Thrombocytopenia in malaria. J Coll Physicians Surg Pak. 2009, 19:708-10.

2. Schlagenhauf-Lawlor P: Travelers Malaria. BC Decker, Inc, Ontario; 2007.

3. Collins WE: Plasmodium knowlesi: a malaria parasite of monkeys and humans . Annu Rev Entomol. 2012, 57:107-21. 10.1146/annurev-ento-121510-133540

4. Chin W, Contacos PG, Coatney GR, Kimball HR: A naturally acquired quotidian-type malaria in man transferable to monkeys. Science. 1965, 149:865. 10.1126/science.149.3686.865

5. McCutchan TF, Piper RC, Makler MT: Use of malaria rapid diagnostic test to identify Plasmodium knowlesi infection. Emerg Infect Dis. 2008, 14:1750-52.

6. Yasinzai MI, Kakarsulemankhel JK: Incidence of human malaria infection in Barkhan and Kohlu, bordering areas of East Balochistan. Pak J Med Sci. 2008, 24:306-10.

7. Coelho HCC, Lopes SCP, Pimentel JPD, et al.: Thrombocytopenia in Plasmodium vivax malaria is related to platelets phagocytosis. PLoS One. 2013, 8:e63410. 10.1371/journal.pone.0063410

8. Sajjanar AB, Dinesh US, Kanbur D, et al.: Hematological parameters in Plasmodium vivax and falciparum malaria - a study at tertiary care centre in North Karnataka. Natl J Lab Med. 2013, 2:23-26.

9. Iron deficiency anaemia assessment, prevention, and control. A guide for programme managers. (1993). Accessed: September 27, 2018:

http://www.who.int/nutrition/publications/en/ida_assessment_prevention_control.pdf.

10. Lathia TB, Joshi R: Can hematological parameters discriminate malaria from nonmalarious acute febrile illness in the tropics?. Indian J Med Sci. 2004, 58:239-44.

11. Patel U, Gandhi G, Friedman S, Niranjan S: Thrombocytopenia in malaria. J Natl Med Assoc. 2004, 96:1212-14.

12. Conte R, Tassi C, Belletti D, et al.: Autoimmune thrombocytopenia in malaria . Vox Sang. 2003, 85:221. 10.1046/j.1423-0410.2003.00348.x

13. Kochar DK, Das A, Kochar A, et al.: Thrombocytopenia in Plasmodium falciparum, Plasmodium vivax and mixed infection malaria: a study from Bikaner (Northwestern India). Platelets. 2010, 21:623-27. 10.3109/09537104.2010.505308

14. Erel O, Vural H, Aksoy N, et al.: Oxidative stress of platelets and thrombocytopenia in patients with vivax malaria. Clin Biochem. 2001, 34:341-44. 10.1016/S0009-9120(01)00221-1

15. Tacchini-Cottier F, Vesin C, Redard M, et al.: Role of TNFR1 and TNFR2 in TNF-induced platelet consumption in mice. J Immunol. 1998, 160:6182-86.

16. Khan FY, Lutof AK, Yassin MA, et al.: Imported malaria in Qatar: a one year hospital-based study in 2005. Travel Med Infect Dis. 2009, 7:111-17. 10.1016/j.tmaid.2009.01.003

17. Srivastava S, Ahmad S, Shirazi N, et al.: Retrospective analysis of vivax malaria patients presenting to tertiary referral centre of Uttarakhand. Acta Trop. 2011, 117:82-85. 10.1016/j.actatropica.2010.10.001

18. George P, Alexander LM: A study on the clinical profile of complicated Plasmodium vivax mono-infections. Asian Pac J Trop Med. 2010, 3:560-62. 10.1016/S1995-7645(10)60135-6

19. Rodríguez-Morales AJ, Sánchez E, Vargas M, et al.: Anemia and thrombocytopenia in children with Plasmodium vivax malaria. J Trop Pediatr. 2006, 52:49-51. 10.1093/tropej/fmi069

20. González B, Rodulfo H, De Donato M, et al.: Hematologic variations in patient with malaria caused by Plasmodium vivax before, during and after treatment. [Article in Spanish]. Invest Clin. 2009, 50:187-201. 
21. Casals-Pascual C, Kai O, Newton CRJC, et al.: Thrombocytopenia in falciparum malaria is associated with high concentrations of IL-10. Am J Trop Med Hyg. 2006, 75:434-36. 10.4269/ajtmh.2006.75.434

22. Tan SO, McGready R, Zwang J, et al.: Thrombocytopaenia in pregnant women with malaria on the Thai-Burmese border. Malar J. 2008, 7:209. 10.1186/1475-2875-7-209

23. Noronha E, Alecrim MG, Romero GA, Macêdo V: Clinical study of falciparum malaria in children in Manaus, AM, Brazil (Article in Portuguese). Rev Soc Bras Med Trop. 2000, 33:18590. 10.1590/S0037-86822000000200005

24. Prasad R, Das BK, Pengoria R, et al.: Coagulation status and platelet functions in children with severe falciparum malaria and their correlation of outcome. J Trop Pediatr. 2009, 55:37478. 10.1093/tropej/fmp028

25. Bouyou-Akotet MK, Mawili Mboumba DP, Kendjo E, et al.: Anaemia and severe malarial anaemia burden in febrile Gabonese children: a nine-year health facility based survey. J Infect Dev Ctries. 2013, 7:983-89. 10.3855/jidc.3347

26. Kiggundu VL, O'Meara WP, Musoke R, et al.: High prevalence of malaria parasitemia and anemia among hospitalized children in Rakai, Uganda. PLoS One. 2013, 8:e82455. 10.1371/journal.pone.0082455

27. Erhart LM, Yingyuen K, Chuanak N, et al.: Hematologic and clinical indices of malaria in a semi-immune population of western Thailand. Am J Trop Med Hyg. 2004, 70:8-14. 10.4269/ajtmh.2004.70.8

28. McKenzie FE, Prudhomme WA, Magill AJ, et al.: White blood cell counts and malaria . J Infect Dis. 2005, 192:323-30. 10.1086/431152

29. Sharma S, Sethi N, Pujani M, et al.: Abnormal WBC scattergram: a clue to the diagnosis of malaria. Hematology. 2013, 18:101-105. 10.1179/1607845412Y.0000000029 